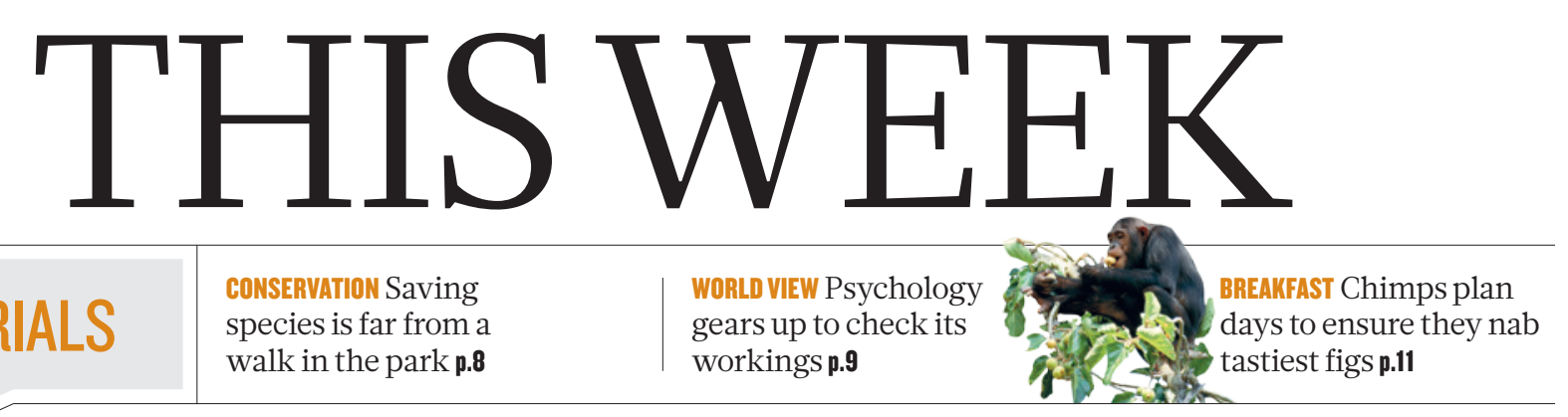

Journals unite for reproducibility

Consensus on reporting principles aims to improve quality control in biomedical research and

encourage public trust in science.

$\mathrm{R}$ eproducibility, rigour, transparency and independent verification are cornerstones of the scientific method. Of course, just because a result is reproducible does not make it right, and just because it is not reproducible does not make it wrong. A transparent and rigorous approach, however, will almost always shine a light on issues of reproducibility. This light ensures that science moves forward, through independent verifications as well as the course corrections that come from refutations and the objective examination of the resulting data.

It was with the goal of strengthening such approaches in the biomedical sciences that a group of editors representing more than 30 major journals; representatives from funding agencies; and scientific leaders assembled at the American Association for the Advancement of Science's headquarters in June 2014 to discuss principles and guidelines for preclinical biomedical research. The gathering was convened by the US National Institutes of Health, Nature and Science (see Science 346, 679; 2014).

The discussion ranged from what journals were already doing to address reproducibility - and the effectiveness of those measures - to the magnitude of the problem and the cost of solutions. The attendees agreed on a common set of Principles and Guidelines in Reporting Preclinical Research (see go.nature.com/ezjl1p) that list proposed journal policies and author reporting requirements in order to promote transparency and reproducibility.

The guidelines recommend that journals include in their information for authors their policies for statistical analysis and how they review the statistical accuracy of work under consideration. Any imposed page limits should not discourage reproducibility. The guidelines encourage using a checklist to ensure reporting of important experimental parameters, such as standards used, number and type of replicates, statistics, method of randomization, whether experiments were blinded, how

the sample size was determined and what criteria were used to include or exclude any data. Journals should recommend deposition of data in public repositories, where available, and link data bidirectionally when the paper is published. Journals should strongly encourage, as appropriate, that all materials used in the experiment be shared with those who wish to replicate the experiment. Once a journal publishes a paper, it assumes the obligation to consider publication of a refutation of that

"The guidelines encourage using a checklist to ensure reporting of important experimental parameters."

source, species, strain, sex, age, husbandry and strain characteristics for transgenic animals. For cell lines, one might report the source, authentication and mycoplasma contamination status. The existence of these guidelines does not obviate the need for replication or independent verification of research results, but should make it easier to perform such replication.

Some of the journals at the meeting had already had all or most of these principles and guidelines in place. But the point is that a large number of scientific journals are standing together in their conviction that reproducibility and transparency are important issues. As partners to the research enterprise in the communication and dissemination of research results, we want to do our part to raise the standards for the benefit of scientists and of society. The hope is that these guidelines will be viewed not as onerous, but as part of the quality control that justifies the public trust in science.

\section{On the mend}

\section{The scientific regeneration of central Europe is gathering pace, but needs further help to thrive.}

\section{$\mathrm{T}$} he peaceful implosion of communism in the autumn of 1989 , almost exactly 50 years after Nazi Germany's assault on Poland triggered the Second World War, was perhaps the brightest moment in Europe's twentieth-century history. The fall of the Berlin Wall restored political and personal freedom to central Europe, where people had endured Hitler's atrocities only to find themselves ruled by Soviet despots. It is a small miracle that the rich learned tradition of the region survived two consecutive tyrannies.
Science in liberated central Europe had to adapt quickly to survive in the free world. Governments, intellectual elites and academic institutions in the region were all equally unprepared for the political sea change that occurred after 1989. A quarter of a century on, the transformation to parliamentarian democracy and a market economy has been achieved. Science was generally not a priority in the early years of the transition. But from 2004 onwards, membership of the European Union (EU) provided a boon that some countries are prudently using to rebuild their research capacities (see page 22). However, despite generous subsidies from Brussels, other countries have a long way to go.

The region's main asset is a growing pool of young talent that is rediscovering science as a worthwhile profession. This generation rightly demands more support and more constructive political vision than some of the region's current governments have to offer. In Romania and Bulgaria, where those in power are stubbornly obstructing reform, science is losing out. And in Hungary, 
where pluralism is under threat, the writing is on the wall.

The last generation of scientists who trained under the communist regime had little faith in science in their countries. When freedom arrived, most of them grasped vastly more lucrative business opportunities or chose to migrate permanently to the West. The resulting shortage of mid-career scientists can be seen in almost any research department in the region. It is also the main reason why central Europe attracts shamefully few grants from the European Research Council and why the region is lagging behind in terms of its overall scientific output (see graphic on page 24).

But interest in science and higher learning is rising sharply. In Poland, student numbers have increased fivefold since 1990. Overall, more than one-quarter of the 20 million students in the EU are now from the new member states. The vast majority of them were born after the demise of communism.

Young scientists do continue to leave, and so they should, but the excessive brain drain has thankfully ceased. Most countries in the region have in recent years created transparent and strictly merit-based science funding systems. But a lot more needs to be done - especially at universities - to help talented young scientists gain independence at an early age. Institutes that do employ young independent group leaders, such as the International Institute of Molecular and Cell Biology in Warsaw, are reaping the benefits. Furthermore, funding agencies across the region should expand, and better advertise, programmes aimed at repatriating young foreign-trained scientists.

Universities in the region are a long way from scoring in the upper ranks of international academic comparisons. But the idea that central Europe remains a poor relation in global science is obsolete.
Since 2004, numerous labs have been re-equipped to facilitate competitive science. The best institutes now offer conditions on a par with those at aspiring labs in Singapore, China or Saudi Arabia. But science managers in central Europe lack the bravado with which the new players in Asia and the Middle East trumpet their strengths and the aggressiveness with which they recruit foreign talent.

The new European Commission that takes office this month must
"The idea that central Europe remains a poor relation in global science is obsolete." help the region to raise its scientific profile. The EU's $€ 80$-billion (US $\$ 100$ billion) Horizon 2020 programme, which started this year, includes a scheme that invites less-potent member states to open new research centres, or upgrade existing ones, in partnership with richer countries. Leading research institutions in the West should accept the invitation.

Collaborations involving high-profile British universities, say, or the prestigious German Max Planck institutes, would no doubt raise the visibility of central European science and help to improve the region's participation in EU-funded research. Structural funds will also remain essential. Billions have already been earmarked for the 2014-20 period, and research is to remain a major beneficiary. But the commission should closely monitor the effectiveness of the investment.

Science is at the heart of the EU's policies. Its renaissance in many parts of central Europe serves as an example of successful European integration at a time when forces threatening the EU's social and political cohesion are gaining strength. Domestic neglect of science in the continent's southeast risks casting the EU's poorer countries even further adrift from the rest of Europe.

\section{Protect the parks}

\section{Balancing the needs of development and conservation is difficult - but urgent.}

\section{$\mathrm{T}$} he World Parks Congress could not be in a better location this year than Sydney, Australia. The gathering of researchers, policy experts and conservationists occurs only once a decade, and it arrives in Australia next week as debate over protection of one of the most famous parks in the nation - and the world — reaches fever pitch.

The Great Barrier Reef is celebrated as one of nature's true wonders. In the popular imagination it is the quintessential coral reef. Millions visit every year to swim in its waters, and millions more dream of such a trip. It is rightly a source of pride for many Australians.

But the reef is in trouble, beset by direct human activity in the form of coastal development and indirect activity in the form of climate change. It exemplifies the problems that congress attendees must struggle with.

The International Union for Conservation of Nature - which oversees the meeting — says that the 2003 parks congress in Durban, South Africa, led to major advances, including ongoing work on protected areas under the Convention on Biological Diversity, and revisions to the system used to manage protected areas.

The world has changed since 2003, when political rhetoric around climate change was still gearing up. Levels of carbon dioxide in the atmosphere - measured at the US National Oceanic and Atmospheric Administration's Mauna Loa observatory in Hawaii - have increased from an average of 375.77 parts per million (p.p.m.) to current peaks of more than 400 p.p.m. on some days, the highest for thousands of years.

It is true that there has been notable progress in creating protected areas, especially in the oceans: huge parks were established in the Pacific by US President George W. Bush and then expanded by President Barack Obama. These join similar areas, including one around the Chagos Islands in the Indian Ocean, created by the United Kingdom.
Progress towards internationally agreed targets to protect $10 \%$ of the world's oceans is slow and behind schedule, but it is progress nonetheless. And growing environmental movements are making themselves heard in rapidly developing economies such as China. In this issue of Nature, seven researchers set out their vision of how the world's parks should develop (page 28). This work is more important than ever.

There have been setbacks. Extensive networks of parks across Africa have failed to safeguard rhinoceroses and elephants from surging poaching. Deforestation continues apace. And the Great Barrier Reef itself has been hard hit, with coral cover falling at a worrying rate (see page 16).

Ecosystems are complex and ever-changing, and it is difficult to prove that protections make a difference. Well-funded and well-organized business lobby groups seek to develop many important areas, and development often still trumps wildlife. People quite legitimately want to improve their own lot, even at the expense of other species. Wealthy nations are able to seal off certain areas for protection, but developing nations in which people rely on subsistence hunting and fishing may not have that luxury.

How to measure the value of the world's ecosystems is still debated. Edward Barbier argues on page 32 that economists tracking growth have done us a disservice by omitting from their calculations the value that has been lost by, for example, turning a mangrove forest into a shrimp farm.

And conservationists still argue over why we should protect the planet - for its economic value or for its own sake. On page 27, Heather Tallis and Jane Lubchenco say that "vitriolic" battles over this tension endanger conservation science. "It is time to re-focus the field of conservation on advancing and sharing knowledge in all relevant disciplines and contexts, and testing hypotheses based on observations, experiments and models," they write in a petition with 238 other signatories.

In conservation, it is often not clear when deadlines are until they have passed. At the next World Parks Congress, around $\rightarrow$ NATURE,COM To comment online, click on Editorials at: go.nature.com/xhunqv 2024, what will attendees discuss? Will there be any truly wild rhinos left? Will the Great Barrier Reef be in terminal decline? Hopefully not. But this year's attendees have their work cut out. 